tions. Dr. Poore thinks that more paper work may be involved, but noted that the responsibilities of the Conservancy remain the same- to acquire and manage the nature reserves, conduct research and publish information. The Nature Conservancy now has to share its eake with a number of other organizations, but the cake is larger, so Dr. Poore feels "there will be more give and take".

In the year ahead Dr. Poore hopes to place greater emphasis on the interaction of the Conservancy's research with its management of the reserves. The most important projects include research in Scotland on the management of grouse and deer, in Wales on the most productive uses of sheep, and a number of projects on productivity and conservation in conjunction with the seven-year International Biological Programme of the International Council of Scientific Unions. In the past the staff may have been too small to apply satisfactorily the results of research, but Dr. Poore hopes that the Nature Conservancy will improve this aspect of its work. chiefly by acting as a catalyst and stimulating and coordinating various bodies to produce guide-lines for future action. One example of such activity is the recent Report on Broadlands (Nature Conservancy, 1965).

\section{Industry at Warwick}

THE new University of Warwick is doing its best not to be an ivory tower above the car works of Coventry. In an attempt to bring industry into close contact with the University, five associate professors from industrial research have joined the teaching staff on a part-time basis, and further appointments are planned. By bringing men from industry into its teaching, Warwick is following a practice long established in such countries as The Netherlands; in the United Kingdom the practice has spread to the Manchester Institute of Science and Technology, the University of Birmingham and the Imperial College of Science and Technology, but Warwick plans to extend this concept to disciplines other than science, including economies, humanities and the social sciences.

Three appointments have been made in the school of molecular science and two in engineering science. The industrialists will give advice, direct research, and take part in postgraduate teaching through lectures and supervision of research. No courses are being given as yet, but a number are planned for the autumn; they will probably take the form of a series of twelve or fourteen lectures.

Graduate students have been using industrial laboratories, such as those at Bristol Siddeley, since the University opened in 1964 (though undergraduates were not admitted until October 1965), but by establishing a more personal contact the University hopes to increase the use of such facilities. Prof. J. A. Shercliff, head of the School of Engineering Science, plans to involve appropriate industrial research organizations as various divisions in his School are set up. For example, Dr. R. H. Macmillan, the director of the Motor Industry Research Association and one of the new associate professors, will be concerned largely with the automotive engineering aspect of the School of Engineering.

In another field, Mr. Peter Hall, director of the Royal Shakespeare Theatre in Stratford, has been appointed associate professor of drama, and the University hopes to start a drama department working in close collaboration with the nearby Royal Shakespeare Company.

\section{Radiobiology at Harwell}

After nearly two decades of existence, the Radiobiological Research Unit of the Medical Research Council at Harwell has grown to be the largest but one of the Council's specialist research units. Yet a recent visit showed that there are still opportunities for the Unit to spread its wings. The facilities, of course, are excellent. The graphite moderated reactor Beppo has, for example, made possible a long-term study of the production of mutations in mice by radiation. The Unit is now reaping a rich harvest of results from this work. Accumulated evidence on the overall effects of genetic mutation suggests that the mouse is less mutable than had been thought. One intriguing finding has been that the frequeney of specific mutations produced by neutron radiation can differ between males and females.

Goats are being used by the Experimental Pathology Group to simulate something like the reactions which human beings might show to acute whole-body neutron irradiation. Apart from lethal dose experiments, the degree of injury to the gut and bone marrow is being investigated. Death within the first few days after irradiation can usually be attributed to injury of the gut, and later deaths, up to 30 days after irradiation, are considered to be the consequence of injury to bone marrow and other tissues. Death from gut damage seems to result from the release of bacteria in the gut into the general circulation.

Adaptations of Moorhead's method for culturing human lymphocytes have proved a great boon to those studying the effects of X-rays and reactor radiation on human chromosomes. The group under Dr. J. Loutit, director of the Unit, is embarking on a study of the chromosome damage produced in these cells by various types of radiation. Dose response and dose-rate effects seem to be linear for neutron radiation, but curvilinear for $\gamma$-radiation.

In the effort of the Radiochemical ( the uptake of radioactive strontium by dietary supplementation, a number of compounds have been tested. Among the most efficacious are calcium phytate and sodium alginate - the latter reducing the strontium-90 uptake by as much as 75 per cent when given as 5 and 10 per cent additives.

\section{Non-symbiotic Nitrogen Fixation}

THere are so many ways for nitrogen to enter and leave the soil that the difficulties of druwing up a nitrogen balance are formidable. The numerous types of microbial action that may be involved, the variations in the experimental data from different parts of the world, and the serious lack of knowledge of the quantitative aspects of many of the processes, make it a complex problem. This applies particularly to non-symbiotic fixation on which a valuable reviow entitled "Non-symbiotic Nitrogen Fixation in Soil and Soil-Plant Systems", by A. W. Moore, is presented in Soils and Fertilizers $(29,113 ; 1966)$. Reliable figures on the rate of accumulation of nitrogen per unit area are still required. However, there is overwhelming evidence that nitrogen is fixed by blue-green algae in rice paddy fields and that the fixation is increased by the presence of the rice plant, a fact of agronomic importance. It is also probable that there is a net gain of nitrogen in other soil-plant systems, such as under forest conditions, but it has not yet been possible to obtain evidence by growing plants satisfactorily in a gas-tight closed system using atmospheres labelled with nitrogen-15. A great many species of micro-organisms have nitrogen-fixing power, and it seems that biological nitrogen fixation is an exothermic reaction, so that a supply of energy is needed only for the growth of the organism. The organism also requires mineral nutrients, adequate moisture, heat and aeration, and probably a suitable $p \mathrm{H}$ range. It is also probable that 'growth factors' are involved and that there are interactions between nitrogen fixing and non-fixing organisms. There remain the possibilities of nitrogen fixation by higher plant tissues and by litter, and of the part played by plant roots.

\section{Malayan Soil Survey Manual}

THE development of agriculture has been accorded a high priority by the Government of the States of Malava. 